\title{
MOLLIE, COUNTESS RUSSELL
}

\author{
IAN WATSON \\ Sociology / Rutgers U. \\ Pósthólf 45I, I2I Reykjavík, Iceland \\ IAN.WATSON@POST.HARVARD.EDU
}

$\mathrm{M}$

arion (Mollie) Cooke was born in Ireland about $1857-58$, the daughter of George Cooke, master shoemaker, and Mary Mitchell. She may have been born at Brackernagh, Ballinasloe (east of Galway) where her father once lived. Her father had moved to Logan Place, Cumbernauld (near Stirling), Scotland by I889 and died there 6 November I89I. Mollie had a brother John, living in I89I in Dublin, and a sister Ellen.

She married her first husband, my great-grandfather James Watson, on 28 February I88I in Glasgow, Scotland. He was born in Dundee, Scotland on 8 June 1851. He had attended the Albert Agricultural Training Establishment in Dublin in 1874-75, and several of his siblings also had close Irish connections. His father, also James Watson, was for many years treasurer of the Dundee Harbour Trust. James and Mollie had a son Stanley James Watson, born 3 April I88I in Glasgow.

The marriage broke down when James Watson's interest in spiritualism (not shared by Mollie, but more mainstream at the time than it would be today) led him to join a utopian spiritualist community called "Shalam" which was forming near Las Cruces, New Mexico. He left for America on 3 October I884, without Mollie. From Mollie's testimony in the divorce proceedings, it appears that it was left unsettled whether he intended to send for her later; in any case, he did not. There are many books and articles about the colony, which was headed by a New York dentist named John B. Newbrough, and which, like many such communities, soon broke up. 
In I888, by then living in Aberdeen, Scotland with their son, Mollie filed for divorce, which was granted the following year. On 30 June 1889 in Chicago, James Watson married Nellie Florence Jones, who had also been a member of the Shalam colony. They moved to Los Angeles, where they had two children, the eldest being my grandfather James M. Watson. They were divorced in Los Angeles in 1903. James Watson died at his son's home in Los Angeles on I2 April 1935.

On 23 July 1889 in Aberdeen, Mollie married George John Somerville, an electrician. Their son John Alec Somerville was born in Aberdeen on 29 September 1889, and their son George Cooke Somerville on I9 July I890. At this point the family disappears from Scottish records, and it seems likely that they moved to England around this time.

George Santayana describes Mollie in his memoirs Persons and Places as "a fat, florid, coarse Irishwoman of forty [in I895], with black curls, friendly manners and emotional opinions; a political agitator and reformer":

Mollie was a good soul. I think it was a relief to her to give up her politics and "social work"; she retained only a natural motherly kindness to servants and to village children, and to me also, for which I was grateful. She knew what poverty was, and didn't overdo acting the grand lady; remained simple and active, and ready, as it were, to relapse at any moment into her native paddydom without much minding it. She had been an orphan or a foundling, picked up and adopted by a small Irish official or tradesman, who married her later; and she had a grown-up son who bore his name. The old man had died, and now she had two small boys by a second husband, who had brought her to live in London and introduced her to politics and social reform. In those circles she had caught sight of Russell, and Cupid had done the rest. ${ }^{\mathrm{I}}$

I have not tried to find the record of Mollie's divorce from George John Somerville. He is likely the George J. Somerville, electrical engineer, age 50, born in Scotland, living alone at 23 Calthorpe Street, St. Pancras, London, in the I90I census.

By the late I89os Mollie was living near London where she met Frank Russell, the 2nd Earl Russell, Bertrand Russell's elder brother, in a politi-

I Persons and Places: Fragments of Autobiography; Critical Edition, ed. William G. Holzberger and Hermann J. Saatkamp, Jr. (Cambridge, Mass.: Miт P., I986), pp. 4767. The volume includes a photograph of Mollie. 
cal context. It was their desire to marry that precipitated the trip to America, Nevada divorce, and Nevada marriage that resulted in Frank Russell's bigamy trial in the House of Lords and subsequent imprisonment when he wrote his Lay Sermons. Her son Stanley James Watson, by then a teenager, joined them in America. The I90I census shows the three of them living together in Amberley Cottage where Stanley James Watson was working as private secretary (presumably to Frank). Mollie's two Somerville sons, who are not living with her in the census, are almost certainly the "Ian" and George Somerville, aged II and Io and both born in Scotland, boarding with school principal Rev. John Botheras at I4 Westbourne Rd., Lewisham, London.

Mollie and Frank were divorced in 1916, she suing him. Frank seems to look back quite fondly at Mollie in his memoirs, My Life and Adventures (1923), perhaps because of his disastrous third marriage to Elizabeth von Arnim.

As Marion, Countess Russell, Mollie published two novels both of which are held by the Bertrand Russell Archives: Five Women and a Caravan (London: Eveleigh Nash, I9II) and An Excellent Mystery (London: Stephen Swift, I9I2). The latter book is dedicated to Frank, and the copy in the Archives is inscribed to Upton Sinclair. The Archives also hold copies of two of her letters (to Bertrand Russell). She also published a one-act play entitled The Matchmakers (London: H. F. W. Deane \& Sons, 1929). Bertrand Russell mentions Five Women and a Caravan: "In it she always alluded to my brother as 'my owner'."

The "Marion Countess Russell Fund" was constituted and supplemented by three deeds, dated I4 September 1914, I2 September I92I and 2 November 1929. This fund seems to have been a trust fund for Frank's divorce settlement to her. Santayana suggests there was (a then illegal) collusion in the divorce, in which this settlement may have played a role.

After Frank Russell's death in I93I, Bertrand Russell had to pay a yearly sum to Mollie for the rent of Telegraph House, as a continuation of her alimony settlement with Frank. Bertrand Russell wrote in his Autobiography: "His [Frank's] second wife, who was very fat, used to wear green corduroy knickerbockers.... Her day ... came to an end.... Molly, from whom he wished to be divorced, demanded $£_{4}$ oo a year for life as her price; after his death, I had to pay this. She died at about the age of ninety" (Auto., 2: 153). Russell sold Telegraph House in 1937. In his Selected Letters, the editor says that the proceeds of Telegraph House 
went into a trust "from which Mollie was the principal beneficiary"; "the sale reduced the amount he had to pay her" (SLBR, 2: 35I).

Mollie's will is dated to October 1938 and leaves everything to her son John Alec Somerville. Mollie died on I4 August 1942. She was about 84, not 90.

Her eqldest son, Stanley James Watson, died in Salford, near Manchester, 8 December 1950, and is buried in Agecroft Cemetery. It seems that he had no children, but late in life he married a woman named Hannah (Dearden) Monks, who may have been his landlady, and to whom all his estate was left. On his death certificate his occupation is listed as Managing Director (Electrical Engineers), which must reflect the influence of his two stepfathers.

The foregoing details about Mollie Russell's life are those that are easily available from printed sources and public records, including the birth, death, marriage, divorce, census, and probate records of all those involved.

Primarily motivated by curiosity about my own family history, I would be most interested to hear from anyone with any more information about Mollie Russell, Stanley James Watson, John Alec Somerville, or George Cooke Somerville. This might include letters, photographs, or reminiscences, as well as information on the whereabouts of any papers Mollie may have left. 